\title{
Potassium nutrition as a strategy to mitigate salt stress in melon grown under protected cultivation
}

\author{
Nutrição potássica como estratégia mitigadora do \\ estresse salino em melões em cultivo protegido
}

Giordanio Bruno Silva Oliveira'; Francisco de Assis de Oliveira²*; Sandy Thomaz dos Santos3; Mychelle Karla Teixeira de Oliveira2; Edna Maria Mendes Aroucha²; José Gustavo Lima de Almeida4; Paulo Victor de Menezes; ${ }^{5}$; Mario Jonas Veras

Costa5; Francisco Felipe Barroso Pinto5; Francisco Adênio Teixeira Alves ${ }^{6}$

\section{Highlights}

Salinized nutrient solution reduces the yield of melon grown in substrate.

Salinity did not affect the quality of melon fruits.

Potassium does not reduce the effect of salt stress in melon.

\section{Abstract}

The use of saline water is one of the major challenges of agriculture, as it can cause nutritional imbalances and thus reduce crop yield. This study proposes to examine the efficiency of potassium nutrition as a salt stress-mitigating agent in melon grown in a protected environment. The experiment was laid out in a randomized-block design with ten treatments in a $2 \times 4$ factorial arrangement represented by two melon cultivars (McLaren and SV1044MF) and four nutrient solutions $\left(\mathrm{S}_{1}\right.$ - standard nutrient solution, 2.5 $\mathrm{dS} \mathrm{m}^{-1} ; \mathrm{S}_{2}$ - nutrient solution salinized with $\mathrm{NaCl}, 5.0 \mathrm{dS} \mathrm{m}^{-1} ; \mathrm{S}_{3}$ - nutrient solution salinized with $\mathrm{NaCl}+$ $50 \% \mathrm{~K}_{2} 6.5 \mathrm{dS} \mathrm{m}^{-1}$; and $\mathrm{S}_{4}$ - nutrient solution salinized with $\mathrm{NaCl}+100 \% \mathrm{~K}, 7.5 \mathrm{dS} \mathrm{m}^{-1}$ ). Yield (average fruit weight, production, fruit diameter, internal cavity, and pulp thickness), quality (pulp firmness, total sugars, soluble solids [SS], vitamin $\mathrm{C}, \mathrm{pH}$, titratable acidity [TA] and SS/TA ratio) and nutritional (K, Na and K/Na ratio) variables were evaluated. Plants fertigated with standard nutrient solution showed the highest values for fruit weight $(1,190.6 \mathrm{~g})$, production $(2,381.3 \mathrm{~g}$ per plant), fruit diameter $(13.6 \mathrm{~cm})$ and pulp thickness $(2.6 \mathrm{~cm})$.

1 Student of the Master's Course of the Postgraduate Program in Soil and Water Management, Universidade Federal Rural do Semi-Árido, UFERSA, Mossoró, RN, Brazil. E-mail: giordaniobruno1@gmail.com

2 Profs. Drs., Graduate Course in Agronomy and Postgraduate Program in Soil and Water Management, UFERSA, Mossoró, RN, Brazil. E-mail: thikaoamigao@ufersa.edu.br; mymykar@gmail.com; aroucha@ufersa.edu.br

${ }^{3}$ Student of the Doctoral Course of the Postgraduate Program in Soil and Water Management, UFERSA, Mossoró, RN, Brazil. E-mail: sandy_thomaz@hotmail.com

${ }^{4}$ Researcher, Postharvest Laboratory, UFERSA, Mossoró, RN, Brazil. E-mail: guga@ufersa.edu.br

${ }^{5}$ Students of the Undergraduate Course in Agronomy, UFERSA, Mossoró, RN, Brazil. E-mail: paulo_escoteiro39@ hotmail.com; mariojonasefa@hotmail.com; fellipebarropinto160@gmail.com

${ }^{6}$ Student of the Master's Course of the Postgraduate Program in Crop Science, UFERSA, Mossoró, RN, Brazil. E-mail: adenio.10a@gmail.com

* Author for correspondence

Received: Apr. 28, 2021 - Approved: July 18, 2021 
Cultivar McLaren produced heavier fruits $(931.4 \mathrm{~g})$ with larger diameter $(12.4 \mathrm{~cm})$ and pulp thickness $(2.4$ $\mathrm{cm})$. The addition of $\mathrm{NaCl}$ to nutrient solution induced a reduction in the yield variables but did not influence fruit quality. The addition of extra $\mathrm{K}$ to salinized nutrient solution did not mitigate the deleterious effect of salinity on the yield of melon.

Key words: Cucumis melo L. Mineral nutrition. Potassium. Salinity. Soilless cultivation.

\section{Resumo}

O uso de água salina é um dos principais desafios na produção agrícola, pois pode provocar desbalanço nutricional e, consequentemente, reduzir o rendimento das culturas. Este trabalho teve como objetivo avaliar a eficiência da nutrição potássica como agente atenuador do estresse salino no meloeiro cultivado em ambiente protegido. O delineamento experimental utilizado foi em blocos casualizados, com dez tratamentos arranjados em esquema fatorial $2 \times 4$, sendo dois cultivares de meloeiro (McLaren e SV1044MF) e quatro soluções nutritivas (S1- solução nutritiva padrão, $2,5 \mathrm{dS} \mathrm{m}^{-1} ; \mathrm{S}_{2}$ - solução nutritiva salinizada com $\mathrm{NaCl}, 5,0 \mathrm{dS} \mathrm{m}^{-1} ; \mathrm{S}_{3}$ - solução nutritiva salinizada com $\mathrm{NaCl}+50 \% \mathrm{~K}, 6,5 \mathrm{dS} \mathrm{m}^{-1} ; \mathrm{S}_{4}$ - solução nutritiva salinizada com $\mathrm{NaCl}+100 \% \mathrm{~K}, 7,5 \mathrm{dS} \mathrm{m}^{-1}$ ). As variáveis de rendimento (peso médio de fruto, produção, diâmetro de fruto, cavidade interna e espessura de polpa), qualidade (firmeza de polpa, açúcares totais, sólidos solúveis, vitamina $\mathrm{C}$, pH, acidez titulável e razão SS/AT) e nutrição ( $\mathrm{K}$, Na e razão K/Na) foram avaliadas. Plantas fertirrigadas com solução nutritiva padrão apresentaram maiores valores para peso de frutos (1.190,6 g), produção (2.381,3 g planta-1), diâmetro de fruto $(13,6 \mathrm{~cm})$ e espessura de polpa $(2,6 \mathrm{~cm})$. O cv. McLaren apresentou frutos mais pesados $(931,4 \mathrm{~g})$, com maior diâmetro $(12,4 \mathrm{~cm})$ e espessura de polpa $(2,4 \mathrm{~cm})$. A adição de $\mathrm{NaCl}$ na solução nutritiva provocou redução nas variáveis de rendimento, mas não influenciou a qualidade dos frutos. A adição extra de $\mathrm{K}$ em solução nutritiva salinizada não atenuou o efeito deletério da salinidade sobre o rendimento do meloeiro.

Palavras-chave: Cucumis melo L. Nutrição mineral. Potássio. Salinidade. Cultivo sem solo.

\section{Introduction}

The melon (Cucumis melo L.) holds importance in the Brazilian export basket, as it generates employment and income. In 2019, the melon crop occupied an area of 22,279 ha, which generated a domestic production of $587,692 \mathrm{t}$. Of this total, $95.9 \%$ came from the northeast region of the country, mainly the state of Rio Grande do Norte, which accounted for $60.7 \%$ of national production (Instituto Brasileiro de Geografia e Estatística [IBGE], 2020).

Commercial growing of melon is traditionally held in field conditions. However, studies have recently been developed with cultivation in protected environments using substrate, especially regarding the use of saline water (Dias et al., 2010, 2018; Morais, Aroucha, Oliveira, Medeiros, \& Nascimento, 2019). The melon crop has moderate tolerance to salinity, with its yield dropping at salinity levels greater than $2.2 \mathrm{dS} \mathrm{m-1}$ in the soil saturation extract. Yield losses of $7.2 \%$ have been reported with each unit increase in salinity (Ayers \& Westcot, 1999).

Bothplantgrowthandfruitdevelopment are associated with good nutritional management of the crop, among other factors. In this respect, high concentrations 
of salts in irrigation water may cause osmotic stress, reducing water absorption by plants and promoting the accumulation of toxic ions, which result in cytotoxicity (Taiz, Møller, \& Murphy, 2017). The accumulation of toxic ions, such as $\mathrm{Na}+$, exerts a competitive inhibition effect on the absorption of essential nutrients, such as K+ (Marschner, 2012), which can limit crop growth and development.

In the literature, studies investigating potassium fertilization in melon have described different results regarding qualitative traits (e.g. fruit size and weight) in response to an increase in the Krate in the soil or in hydroponic cultivation (Oliveira, Silva, Medeiros, \& Vieira, 2020; Nascimento, Nascimento, \& Cecílio, 2020; Gratieri, Cecílio, Barbosa, \& Pavani, 2013). Studies can be found on the application of $\mathrm{K}$ as a salt stress-mitigating agent in crops such as peanut (Chakraborty, Bhaduri, Meena, \& Kalariya, 2016), eggplant (Santos et al., 2018) and bell pepper (R. C. P. Silva et al., 2020a). However, no studies have reported its effect on fruit production, yield and quality in melon. Recent investigations have related the beneficial effects of $\mathrm{K}$ in salt-stressed plants to the tolerance of each genotype to salinity, with more evident responses occurring in sensitive genotypes (Chakraborty et al., 2016: Shi et al., 2020).

Adequate potassium nutrition can lessen the adverse effect of salt stress by regulating stomatal opening and closure, the maintenance of ionic balance in the cell membrane and protein synthesis (Dawood, Abdelhamid, \& Schmidhalter, 2014). In melon, Kaya, Tuna, Ashraf, \& Altunlu (2007) observed that $K$ reduced the deleterious effect of salinity by maintaining membrane permeability and increasing the calcium, nitrogen and potassium contents in the leaf tissue.
The maintenance of adequate $\mathrm{K}$ levels in the leaf tissue of plants is known to play a crucial role in their survival under saline conditions. On this basis, the present study was developed to examine the efficiency of potassium nutrition as a salt stress-mitigating agent in melon cultivars grown in a protected environment.

\section{Material and Methods}

The experiment was developed from July to September 2018 in a greenhouse at the Department of Agronomic and Forestry Sciences, Federal Rural University of the Semiarid (UFERSA), located in Mossoró - RN,

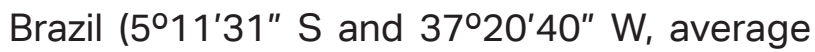
altitude $18 \mathrm{~m})$.

A randomized-block experimental design was implemented with a $2 \times 4$ factorial arrangement and three replicates. The treatments were formed by the combination of two melon cultivars, namely, McLaren ('Gália') and SV1044MF ('Cantaloupe') and four nutrient solutions $\left(\mathrm{S}_{1}\right.$ - standard nutrient solution, 2.5 $\mathrm{dS} \mathrm{m}^{-1} ; \mathrm{S}_{2}$ - nutrient solution salinized with $\mathrm{NaCl}, 5.0 \mathrm{dS} \mathrm{m}-1 ; \mathrm{S}_{3}$ - nutrient solution salinized with $\mathrm{NaCl}+50 \% \mathrm{~K}, 6.5 \mathrm{dS} \mathrm{m}^{-1}$; and $\mathrm{S}_{4}$ - nutrient solution salinized with $\mathrm{NaCl}+100 \% \mathrm{~K}, 7.5 \mathrm{dS}$ $\left.\mathrm{m}^{-1}\right)$. The experimental unit was represented by three pots with a capacity of $10 \mathrm{dm}^{3}$, which contained a substrate composed of a mixture of coconut fiber and sand (2:1), and one plant per pot.

Table 1 shows the amounts of fertilizers used in each nutrient solution. The micronutrients were supplied via the Rexolim ${ }^{\circledR}$ fertilizer, whose components and concentrations are as follows: $11.6 \%$ potassium oxide $\left(\mathrm{K}_{2} \mathrm{O}\right), 1.28 \%$ sulfur $(\mathrm{S})$, 
$0.86 \%$ magnesium (Mg), 2.1\% boron (B), 0.36\% copper $(\mathrm{Cu}), 2.66 \%$ iron $(\mathrm{Fe}), 2.48 \%$ manganese $(\mathrm{Mn}), 0.036 \%$ molybdenum (Mo) and $3.38 \%$ zinc $(Z n)$. The fertilizer was used at the rate of $30 \mathrm{~g}$ per $1000 \mathrm{~L}$, as recommended on the packaging for vegetables in general.

\section{Table 1}

Salt content (g $\left.1000 \mathrm{~L}^{-1}\right)$ and electrical conductivity of the nutrient solutions used in the experiment

\begin{tabular}{|c|c|c|c|c|}
\hline \multirow[b]{2}{*}{ Salt } & \multicolumn{4}{|c|}{ Nutrient solution } \\
\hline & $\mathrm{S}_{1}^{*}$ & $\mathrm{~S}_{2}$ & $\mathrm{~S}_{3}$ & $\mathrm{~S}_{4}$ \\
\hline Calcium nitrate & 900 & 900 & 900 & 900 \\
\hline Potassium nitrate & 455 & 455 & 455 & 455 \\
\hline Monoammonium phosphate & 170 & 170 & 170 & 170 \\
\hline Magnesium sulfate & 246 & 246 & 246 & 246 \\
\hline Potassium chloride & 100 & 100 & 150 & 200 \\
\hline Sodium chloride & - & 465 & 465 & 465 \\
\hline Final electrical conductivity ( $\mathrm{dS} \mathrm{m}^{-1}$ ) & 2.5 & 5.0 & 6.5 & 7.5 \\
\hline
\end{tabular}

* Castellane and Araújo (1994).

The lower-salinity water was collected from the supply system of the central campus of UFERSA. Physicochemical analyses revealed the following characteristics: $\mathrm{pH}=$ 7.57; electrical conductivity $=0.52 \mathrm{dS} \mathrm{m}^{-1} ; \mathrm{Ca}^{2+}$ $=0.83 ; \mathrm{Mg}^{2+}=1.20 ; \mathrm{K}^{+}=0.32 ; \mathrm{Na}^{+}=3.76 ; \mathrm{Cl}^{-}$ = 2.40; $\mathrm{HCO}_{3}=3.10 ;$ and $\mathrm{CO}_{3}{ }^{2-}=0.57$ (mmolc $\mathrm{L}-1)$. The other water salinity levels were achieved by adding $\mathrm{NaCl}$ to the lower-salinity water and adjusting electrical conductivity with a conductivity meter. Planting was carried out by direct sowing in plastic pots containing a substrate formulated by a mixture of coconut fiber and washed sand (2:1), using two seeds per pot. Five days after emergence, the plants were thinned, leaving one plant in each pot.

The pots were arranged inside the greenhouse on $0.2 \mathrm{~m}$-high concrete blocks, at a spacing of $1.0 \mathrm{~m}$ between rows and 0.5 $\mathrm{m}$ between plants. As the plants developed, the lateral branches were shoot-pruned up to the eighth node, and from that node the plants were trained with two stakes.

Along each row of plants, trellises were set up with wooden stakes and stainless steel wires to provide the vertical development of branches and help in staking, which was conducted using plastic ribbons. These ribbons were tied around the plant neck and fixed to the steel wires in a vertical direction so that the stems would wind around the ribbon as they grew. Preventive phytosanitary control was carried out periodically using products and the recommended rates for vegetables. At the end of the experiment, the plants were sprayed three times with $\mathrm{Orfeu}^{\circledR}$ (active ingredient: acetamiprid), Fegatex ${ }^{\circledR}$ (active ingredient: benzalkonium chloride) and the organic acaricide Tarssus Green ${ }^{\circledR}$. 
An independent drip irrigation system was used for each nutrient solution. The lateral lines were composed of flexible polyethylene tubes with an internal diameter of $16 \mathrm{~mm}$ and microtube ("spaghetti") emitters with an internal diameter of $1.0 \mathrm{~mm}$, using one emitter per pot. The application of different nutrient solutions, according to each treatment, began ten days after sowing, using the same nutrient rates for all treatments except potassium, which varied between treatments.

Fertigation was controlled using a timer, with six daily irrigations. The duration of each irrigation procedure was adjusted according to the need of the crop. The plants were initially irrigated six times daily for $30 \mathrm{~s}$ per operation. From the beginning of flowering until harvest, the duration of each irrigation was extended to $1.0 \mathrm{~min}$.

Pollination was carried out manually as the male and female flowers emerged. To increase efficiency, pollination was performed in the early morning hours, as pollen grains have their viability reduced throughout the day. After fruit set, the plants were thinned to leave two fruits per plant. Then, the fruits were packed in nylon bags that were fixed to the wire of the staking system to help support the plants.

The fruits were harvested 70 days after sowing, then placed in boxes and transported to the Food Technology Laboratory at UFERSA, where they were analyzed for the following variables: average fruit weight (FW, $\mathrm{g} /$ fruit), measured with an analytical balance $(0.01 \mathrm{~g})$ and using the two fruits harvested from each plant; fruit diameter (FD, cm), measured transversely with a graduated ruler; internal cavity (IC, cm), measured based on the longitudinal and transverse measurements of the internal fruit cavity, disregarding the pulp, with a digital caliper; pulp thickness (PT, mm), the average of the thickness measured at two opposite points of the fruit pulp, with a digital caliper; and pulp firmness (PF, N), measured as penetration resistance, using a penetrometer with an $8.0-\mathrm{mm}$ diameter cylindrical tip plunger. The fruit was cut lengthwise and two measurements were taken directly on the pulp on each side of the fruit. Results were obtained in pounds-force (ibf) and converted to Newton (N) using the conversion factor of 4.45 .

The soluble solids (SS) content was determined in the homogenized fruit juice, with results expressed in ${ }^{\circ}$ Brix. Titratable acidity (TA) was determined according to the Adolfo Lutz Institute [IAL] (2008), by titrating a 10-g aliquot of juice containing $40 \mathrm{~mL}$ of distilled water, in the presence of $1 \%$ phenolphthalein, with a $0 \% 0.02 \mathrm{~N} \mathrm{NaOH}$ solution, until the color changed to slightly pink; results were expressed in \% citric acid.

The $\mathrm{pH}$ was measured in the juice of the fruits of each treatment using a digital potentiometer with a glass membrane that was calibrated with $\mathrm{pH} 7.0$ and 4.0 buffers (Association of Official Agricultural Chemists [AOAC], 1992). Total soluble solids/titratable acidity ratio (SS/TA) was determined by dividing the two variables. The total soluble sugar content (TSS) was determined using fruit juice, following the methodology of Yemn and Willis (1954). Finally, the vitamin C content was measured by neutralization titration with a DFI solution $(0.02 \%$ 2,6-dichlorophenolindophenol), with results expressed in $\mathrm{mg} 100 \mathrm{~g}^{-1}$ ascorbic acid.

To determine the $\mathrm{K}$ and $\mathrm{Na}$ contents, six leaves were collected from each plant in full bloom. These were placed in paper bags 
and dried in a forced-air oven at a temperature of $65^{\circ} \mathrm{C}$ until reaching a constant weight. After drying, the samples were ground in a Wiley mill and then subjected to sulfuric digestion to obtain the extracts. Potassium and $\mathrm{Na}$ readings were taken by flame photogrammetry (Empresa Brasileira de Pesquisa Agropecuária [EMBRAPA], 2009).

Data were subjected to analysis of variance (ANOVA) and the factors were decomposed when there was a significant response to the interaction between the factors. The effect of the treatments was analyzed using a mean-comparison test (Tukey's test at 5\% significance). Statistical analyses were performed using SISVAR statistical software (Ferreira, 2014).

\section{Results and Discussion}

\section{Fruit yield components}

Yield components were influenced only by the genotypes and nutrient solutions, except for internal cavity (IC), which was influenced only by the nutrient solution factor (Table 2). The cultivars differed from each other for the variables of fruit weight (FW), production, fruit diameter (FD) and pulp thickness (PT), for which cv. McLaren showed 18.5, 18.5, 5.7 and $16.5 \%$ higher values, respectively, than SV1044MF. There was no difference between cultivars for IC, which averaged $6.4 \mathrm{~cm}$ (Table 2). As all plants were trained with two fruits per plant, the effect of the applied treatments on production was directly related to fruit weight.
Concerning the effect of nutrient solutions, the addition of $\mathrm{NaCl}$ to nutrient solution (S2) caused FW, production, FD and IC to decrease by 27.8, 27.8, 11.4 and $13.7 \%$, respectively, when compared with the standard nutrient solution (S1). The extra addition of $\mathrm{K}$ was not efficient to lessen the effect of salt stress on these variables. Contrary to expectations, the higher concentration of $\mathrm{K}(100 \%)$ increased the deleterious effect of salinity on FW and FD, which resulted in losses of $17.7 \%$ for $\mathrm{FW}$ and $6.7 \%$ for FD, as compared with the results obtained with solution $\mathrm{S}_{2}$ (Table 2 ).

Pereira et al. (2017) observed a significant reduction in the size, weight and longitudinal and transverse diameters of melon fruit. According to Dias et al. (2010), salinity reduces the availability of water and nutrients to plants, resulting in losses in average fruit weight as the salt concentration increases. In a soil cultivation experiment, Oliveira et al. (2020) did not observe a significant response from fruit quality traits. Nascimento et al. (2020) described similar findings working with melon in hydroponics, where the $\mathrm{K}$ concentrations also did not affect the fruit size-related variables. In contrast, Gratieri et al. (2013) analyzed the effect of $N$ and $K$ rates on melon grown in coconut fiber and found an increase in fruit weight as the $\mathrm{K}$ rates were increased, but the authors also noted that the $\mathrm{K}$ effect only occurred at high $\mathrm{N}$ rates. 


\section{Table 2}

Fruit weight (FW), production, fruit diameter (FD), internal cavity (IC) and pulp thickness (PT) in melon cultivars subjected to potassium concentrations in the salinized nutrient solution

$\begin{array}{cccccc}\text { Cultivar } & \begin{array}{c}\text { FW } \\ \text { g fruit }^{-1}\end{array} & \begin{array}{c}\text { Production } \\ \text { g plant }^{-1}\end{array} & \begin{array}{c}\text { FD } \\ \mathrm{cm}\end{array} & \begin{array}{c}\text { IC } \\ \mathrm{cm}\end{array} & \begin{array}{c}\text { PT } \\ \mathrm{cm}\end{array} \\ \text { McLaren } & 931.0 \mathrm{a} & 1863.1 \mathrm{a} & 12.4 \mathrm{a} & 6.5 \mathrm{a} & 2.378 \mathrm{a} \\ \text { SV1044MF } & 785.4 \mathrm{~b} & \begin{array}{c}1570.8 \mathrm{~b} \\ \text { Nutrient solution }\end{array} & 11.7 \mathrm{~b} & 6.2 \mathrm{a} & 2.041 \mathrm{~b} \\ \text { S1 } & 1190.7 \mathrm{a} & 2381.3 \mathrm{a} & 13.6 \mathrm{a} & 7.3 \mathrm{a} & 2.570 \mathrm{a} \\ \text { S2 } & 860.2 \mathrm{~b} & 1720.3 \mathrm{~b} & 12.0 \mathrm{~b} & 6.3 \mathrm{~b} & 2.271 \mathrm{ab} \\ \text { S3 } & 674.2 \mathrm{~b} & 1348.3 \mathrm{~b} & 11.3 \mathrm{~b} & 5.9 \mathrm{~b} & 1.971 \mathrm{~b} \\ \text { S4 } & 707.8 \mathrm{~b} & 1415.7 \mathrm{~b} & 11.2 \mathrm{~b} & 6.1 \mathrm{~b} & 2.024 \mathrm{~b} \\ \text { CV (\%) } & 16.6 & 17.24 & 5.58 & 7.13 & 10.45\end{array}$

$\mathrm{ns}^{*}{ }^{*}$ and ${ }^{* *}=$ not significant and significant at 5 and $1 \%$, respectively. Mean values followed by the same letter in the columns do not differ from each other by Tukey's test $(\mathrm{p} \leq 0.05)$. $\mathrm{S}_{1}$ - standard nutrient solution, $2.5 \mathrm{dS} \mathrm{m}^{-1} ; \mathrm{S}_{2}$ - nutrient solution salinized with $\mathrm{NaCl}, 5.0 \mathrm{dS} \mathrm{m}^{-1} ; \mathrm{S}_{3}$ - nutrient solution salinized with $\mathrm{NaCl}+50 \% \mathrm{~K}, 6.5 \mathrm{dS} \mathrm{m}^{-1} ; \mathrm{S}_{4}$ - nutrient solution salinized with $\mathrm{NaCl}+100 \% \mathrm{~K}, 7.5 \mathrm{dS} \mathrm{m}^{-1}$.

The lack of responses to $\mathrm{K}$ rates under salt stress can be attributed to the high electrical conductivity of the nutrient solution that was provided by the addition of both $\mathrm{NaCl}$ and $\mathrm{KCl}$, used for the extra $\mathrm{K}$ addition (Table 1). Moreover, the excess $K$ may have caused nutritional imbalance due to the negative interaction between the $\mathrm{K}^{+}$ion and other cations, such as $\mathrm{Ca}^{2+}$ and $\mathrm{Mg}^{2+}$ (Marschner, 2012)

In the present study, IC showed the same response as that described by Dias et al. (2018), who reported a reduction in this variable at salinity levels greater than $3.0 \mathrm{dS}$ $\mathrm{m}^{-1}$. Queiroz (2016) worked with 'Gália' melon grown in fiber substrate and fertigated under $\mathrm{K}$ concentrations and found an increase in IC in response to the increasing $\mathrm{K}$ rates; however, no salinized nutrient solution was used.

The increasing salinity in the nutrient solution provided by the addition of $\mathrm{NaCl}$ did not affect PT. However, the addition of $50 \%$ and $100 \%$ extra $\mathrm{K}\left(\mathrm{S}_{3}\right.$ and $\left.\mathrm{S}_{4}\right)$ reduced $\mathrm{PT}$. These results corroborate those described by M. C. Silva, Silva, Bonfim-Silva and Farias (2014), who worked with $\mathrm{N}$ and $\mathrm{K}$ rates in melon and found a reduction in PT at the highest $\mathrm{K}$ rates. Queiroz (2016) detected a reduction in the thickness of melon pulp in response to the increase in $\mathrm{K}$ concentration. Nevertheless, it is important to stress that these authors did not use salinized water in the preparation of the nutrient solution, which can alter the crop's response to potassium nutrition.

\section{Fruit quality components}

Nutrient solution and genotype affected the physicochemical traits of the fruits (Table 3 ). The nutrient solutions influenced the titratable acidity (TA) of the fruits, whose highest values occurred with 
the addition of $\mathrm{NaCl}$ combined with the extra addition of $50 \% \mathrm{~K}\left(\mathrm{~S}_{3}\right)$. This result did not differ from those achieved with the other salinized nutrient solutions. However, the $\mathrm{K}$ rates did not affect TA (Table 3).

\section{Table 3}

Titratable acidity (TA), SS (soluble solids)/TA ratio and pH in the fruit juice of melon cultivars subjected to potassium concentrations in salinized nutrient solution

\begin{tabular}{|cccc|}
\hline Cultivar & TA* $^{*}$ & SS/TA & pH \\
\hline McLaren & $0.11 \mathrm{a}$ & $86.1 \mathrm{a}$ & $6.1 \mathrm{a}$ \\
SV1044MF & $0.12 \mathrm{a}$ & $79.1 \mathrm{~b}$ & $5.9 \mathrm{~b}$ \\
\hline Nutrient solution & & & \\
$\mathrm{S}_{1}$ & $0.11 \mathrm{~b}$ & $91.3 \mathrm{a}$ & $6.2 \mathrm{a}$ \\
$\mathrm{S}_{2}$ & $0.12 \mathrm{ab}$ & $88.1 \mathrm{a}$ & $6.1 \mathrm{ab}$ \\
$\mathrm{S}_{3}$ & $0.13 \mathrm{a}$ & $72.0 \mathrm{~b}$ & $5.7 \mathrm{c}$ \\
$\mathrm{S}_{4}$ & $0.12 \mathrm{ab}$ & $80.6 \mathrm{ab}$ & $5.8 \mathrm{bc}$ \\
$\mathrm{CV}(\%)$ & 7.62 & 9.28 & 3.12 \\
\hline
\end{tabular}

* expressed as \% of citric acid. Mean values followed by the same letter in the columns do not differ from each other by Tukey's test $(\mathrm{p} \leq 0.05)$. $\mathrm{S}_{1}$ - standard nutrient solution, $2.5 \mathrm{dS} \mathrm{m}^{-1} ; \mathrm{S}_{2}$ - nutrient solution salinized with $\mathrm{NaCl}_{1} 5.0 \mathrm{dS} \mathrm{m}^{-1} ; \mathrm{S}_{3}$ - nutrient solution salinized with $\mathrm{NaCl}+50 \% \mathrm{~K}, 6.5 \mathrm{dS} \mathrm{m}^{-1} ; \mathrm{S}_{4}$ - nutrient solution salinized with $\mathrm{NaCl}+100 \% \mathrm{~K}, 7.5 \mathrm{dS} \mathrm{m} \mathrm{m}^{-1}$.

Increases in TA in melon fruits in response to salinity have also been reported in soil (Gurgel, Oliveira, Gheyi, Fernandes, \& Uyeda, 2010) and hydroponic (Dias et al., 2018) cultivation. In this regard, Gurgel et al. (2010) also found no effect of $\mathrm{K}$ on TA, regardless of irrigation water salinity. Oliveira et al. (2020) worked with melon cultivated in soil and found an increase in TA in fruits harvested from plants fertigated with higher $\mathrm{K}$ rates, but the authors did not use saline water for irrigation, which may have induced a greater effect of $\mathrm{K}$ on the plants.

Cultivar McLaren was superior to SV1044MF for the variables of SS/TA ratio and $\mathrm{pH}$. There was no significant difference between the cultivars for TA (Table 3). In analyzing the effect of nutrient solutions on SS/TA and $\mathrm{pH}$, we observe that the addition of
$\mathrm{NaCl}$ to the solution $\left(\mathrm{S}_{2}\right)$ did not influence either variable. However, the extra $\mathrm{K}$ addition at $50 \%$ $\left(S_{3}\right)$ provided the lowest ratios, whereas the lowest $\mathrm{pH}$ values occurred with solutions $\mathrm{S}_{3}$ and $\mathrm{S}_{4}$ (Table 3). The SS/TA ratio also known as maturation index is an important trait in the evaluation of fruit flavor. Soluble solids are mainly composed of sugars, including fructose, sucrose and glucose. Therefore, a high SS/TA ratio indicates sweeter fruits (Chitarra \& Chitarra, 2005).

In an experiment investigating the quality of fruits produced in a greenhouse under salinity levels, Dias et al. (2018) observed a tendency towards a decrease in $\mathrm{pH}$ at the salinity level of $4.9 \mathrm{dS} \mathrm{m}^{-1}$. Oliveira (2020) worked with melon at different concentrations of $\mathrm{N}$ and $\mathrm{K}$ applied via fertigation and also detected a tendency towards a pH decline in 
treatments with higher amounts of fertilizers applied. In the present study, the $\mathrm{pH}$ decline seen in the solutions with more potassium is possibly due to the greater presence of this cation in the pulp and its possible effect on fruit maturation. In this respect, it would be appropriate to check if there are studies relating minerals in the pulp with their amount in the soil or hydroponic solution, since this variable was not studied in our experiment.

The interaction between the studied factors affected pulp firmness (PF), total soluble sugars (TSS), SS and vit. C (Table 4). In terms of $P F$, the cultivars differed when subjected to nutrient solutions $S_{2}$ and $S_{4^{\prime}}$ with Cv. McLaren being superior in $S_{2}$, but inferior in $\mathrm{S}_{4}$ (Table 4). In this cultivar, PF was not significantly influenced by the solutions, averaging $38.7 \mathrm{~N}$. In cv. SV1044MF, the plants fertigated with salinized nutrient solution enriched with $100 \% \mathrm{~K}\left(\mathrm{~S}_{4}\right)$ produced fruits with greater $\mathrm{PF}$, which was $25.1 \%$ higher in comparison with the values obtained by this cultivar in standard nutrient solution (Table 4).

\section{Table 4}

Pulp firmness, total soluble sugars, soluble solids and vitamin C in fruit juice of melon cultivars subjected to potassium concentrations in salinized nutrient solution

\begin{tabular}{|c|c|c|c|c|c|}
\hline \multirow{2}{*}{ Cultivar } & \multicolumn{5}{|c|}{ Nutrient solution } \\
\hline & S1 & S2 & S3 & S4 & Mean \\
\hline \multicolumn{6}{|c|}{ Pulp firmness (N) } \\
\hline McLaren & $42.3 \mathrm{Aa}$ & $44.9 \mathrm{Aa}$ & $40.2 \mathrm{Aa}$ & $27.6 \mathrm{Ab}$ & 38.7 \\
\hline SV1044MF & $35.4 \mathrm{Ba}$ & $34.8 \mathrm{Bb}$ & $32.1 \mathrm{Ba}$ & 44.3 Aa & 36.6 \\
\hline Mean & 38.8 & 39.81 & 36.16 & 35.90 & \\
\hline \multicolumn{6}{|c|}{ Total soluble sugars (\%) } \\
\hline McLaren & $5.6 \mathrm{Ba}$ & $6.0 \mathrm{ABa}$ & $5.8 \mathrm{ABa}$ & 8.4 Aa & 6.4 \\
\hline SV1044MF & $5.5 \mathrm{Aba}$ & $7.2 \mathrm{Aa}$ & 3.7 Bb & $4.8 \mathrm{ABb}$ & 5.3 \\
\hline Mean & 5.5 & 6.6 & 4.8 & 5.6 & \\
\hline \multicolumn{6}{|c|}{ Soluble solids ( ${ }^{\circ} \mathrm{Brix}$ ) } \\
\hline McLaren & $9.9 \mathrm{Aa}$ & 10.3 Aa & 10.0 Aa & 10.1 Aa & 10.1 \\
\hline SV1044MF & $10.3 \mathrm{Aa}$ & 9.8Aba & $8.7 \mathrm{Bb}$ & $9.1 \mathrm{Bb}$ & 9.5 \\
\hline Mean & 10.1 & 10.0 & 9.3 & 9.6 & \\
\hline \multicolumn{6}{|c|}{ Vitamin $\mathrm{C}\left(\mathrm{mg} 100 \mathrm{~mL}^{-1}\right)$} \\
\hline McLaren & $13.4 \mathrm{Bb}$ & $25.8 \mathrm{Aa}$ & $14.5 \mathrm{Ba}$ & $27.2 \mathrm{Ba}$ & 20.2 \\
\hline SV1044MF & 23.3 Aa & 16.7 Bb & 13.0 Ba & $12.6 \mathrm{Bb}$ & 16.4 \\
\hline Mean & 18.4 & 21.2 & 13.8 & 19.9 & \\
\hline
\end{tabular}

Mean values followed by the uppercase same letter in the rows and lowercase letters in the columns do not differ from each other by Tukey's test ( $\mathrm{p} \leq 0.05)$. $\mathrm{S}_{1}$ - standard nutrient solution, $2.5 \mathrm{dS} \mathrm{m}^{-1} ; \mathrm{S}_{2}$ - nutrient solution salinized with $\mathrm{NaCl}$, $5.0 \mathrm{dS} \mathrm{m}^{-1} ; \mathrm{S}_{3}$ - nutrient solution salinized with $\mathrm{NaCl}+50 \% \mathrm{~K}, 6.5 \mathrm{dS} \mathrm{m}^{-1} ; \mathrm{S}_{4}$ - nutrient solution salinized with $\mathrm{NaCl}+100 \%$ $\mathrm{K}, 7.5 \mathrm{dS} \mathrm{m}^{-1}$. 
The lack of a salinity effect on the firmness of the melon pulp observed in the present study is in agreement with results presented by other authors (Pereira et al., 2017; Dias et al., 2018). This is an essentially important attribute when it comes to postharvest handling, as firmer fruits better resist mechanical injuries during transport and marketing operations. For TSS, the melon cultivars differed across the salinized solutions and the solutions with extra potassium addition $\left(\mathrm{S}_{3}\right.$ and $\left.\mathrm{S}_{4}\right)$. In both solutions, $\mathrm{cv}$. McLaren had a higher TSS content than $\mathrm{cV}$. SV1044MF (Table 4). In solutions $S_{1}$ and $S_{2}$, there was no difference between the cultivars for TSS, which averaged 5.6 and $6.6 \mathrm{~g} / 100 \mathrm{~g}$, respectively (Table 4).

In both cultivars, the nutrient solutions influenced TSS (Table 4). In cv. McLaren, the highest TSS content was found in the fruits fertigated with the salinized solution with extra addition of Kat $100 \%$ (S4). This resultwas $50.8 \%$ higher than the lowest content obtained with the standard solution $\left(\mathrm{S}_{1}\right)$, although these two solutions did not differ from $\mathrm{S}_{2}$ and $\mathrm{S}_{3}$ (Table 4). In cv. SV1044MF, fertigation with $S_{2}$ resulted in the highest TSS value, which decreased by $48.3 \%$ when the plants were subjected to salinized solution with extra addition of $50 \% \mathrm{~K}$ (S3). Solution $\mathrm{S}_{2}$ also did not differ from the $\mathrm{S}_{1}$ or $\mathrm{S}_{4}$ for this variable (Table 4).

Total sugars refer to the total amount of sugars present in the fruit (sucrose, glucose, and fructose), which accumulate in the ripening phase along with a decrease in acidity (Chitarra \& Chitarra, 2005).

The decrease in TSS values in $\mathrm{cV}$. SV1044MF at the highest $\mathrm{K}$ rate (S4), may have been in response to the high electrical conductivity. Accordingly, it may reflect the relocation of these sugars, which instead of accumulating in the fruit, are rerouted to an osmoregulation process (F. H. A. Silva et al., 2020b). Conversely, D. L. Morais et al. (2018) explained that the reduction in total sugars may be linked to lower water and nutrient absorption by plants due to excess salts in the culture medium. As a result, the fruits would require more time to reach the harvest point and remain longer on the plant.

Likewise, Queiroz (2016) observed an increase in TSS in melon in response to $\mathrm{K}$ rates, describing values between 5.0 and $7.0 \mathrm{~g} / 100$ g. D. L. Morais et al. (2018) reported a $11.5 \%$ decrease in total sugars in Cucumis anguria fruits grown at a saline level of $2.0 \mathrm{dS} \mathrm{m}^{-1}$.

The cultivars differed in SS content only under nutrient solutions S3 and S4, with cv. McLaren showing 12.8 and $9.7 \%$ higher values than $\mathrm{cv}$. SV1044MF in the respective solutions (Table 4). There was no significant effect of nutrient solutions on the SS content of cv. Mclaren, which averaged $10.1{ }^{\circ}$ Brix. Cultivar SV1044MF did not respond to the addition of $\mathrm{NaCl}\left(\mathrm{S}_{2}\right)$; however, the addition of extra $\mathrm{K}$ caused a reduction in SS (Table 4). Some studies show no effect of salinity on SS in melon fruits. Gurgel et al. (2010) demonstrated that SS were not changed up to the salinity levels of 3.9 and $3.0 \mathrm{dS} \mathrm{m}^{-1}$, averaging 9.2 and $10.2{ }^{\circ}$ Brix, respectively, regardless of the $\mathrm{K}$ rate. Dantas et al. (2018) and Dias et al. (2018) described a reduction in SS in melon grown under salt stress conditions.

Potassium is classified as "the fruit quality nutrient", as it acts in stomatal opening and closure, enzyme activation, the transport of other nutrients across membranes and sugar translocation (Epstein \& Bloom, 2006). However, the addition of extra $\mathrm{K}$ had no effect 
on the SS content, which disagrees with the results found by M. C. Silva et al. (2014) in melon cultivated in soil. It is important to note that these authors did not work with salt stress, as was the case with Gurgel et al. (2010), who also did not observe an effect of $\mathrm{K}$ on SS in fruits obtained from plants irrigated with saline water.

As regards the vit. C content, cv. McLaren was superior by $74.8 \%$ in solution $\mathrm{S}_{1}$. In solutions $\mathrm{S}_{2}$ and $\mathrm{S}_{4}$, SV1044MF exhibited higher vit. C levels, whose values were 35.6 and $53.9 \%$ greater than those obtained by McLaren in the respective solutions (Table 4). The nutrient solutions influenced the vit. C content. For cv. McLaren, the highest values were obtained using solutions $S_{2}$ and $\mathrm{S}_{4}$, whereas in SV1044MF the highest vit. C contents were detected in the standard nutrient solution (Table 4). The literature has no consensus on the effect of salinity and $\mathrm{K}$ on the vit. $\mathrm{C}$ content of fruits. Ascorbic acid is an important antioxidant molecule in cells. Its biosynthesis in plants is a process not yet fully understood, and it's supposed precursors are mannose and galactose (Koblitz, 2010).

\section{Leaf potassium and sodium contents and K/ Na ratio}

The cultivars differed significantly in their $\mathrm{K}$ and $\mathrm{Na}$ contents, but not $\mathrm{K} / \mathrm{Na}$ ratio. The nutrient solutions influenced the $\mathrm{K}$ and $\mathrm{Na}$ contents and $\mathrm{K} / \mathrm{Na}$ ratio (Table 5 ). Cultivar McLaren had a $17.2 \%$ higher $\mathrm{K}$ content in the leaf tissue than cv. SV1044MF (Table 4). When the effect of nutrient solutions was analyzed, the addition of $\mathrm{NaCl}$ to the nutrient solution $\left(\mathrm{S}_{2}\right)$ was found to cause a $65.5 \%$ reduction in $\mathrm{K}$ content as compared with the standard nutrient solution $\left(\mathrm{S}_{1}\right)$. Although extra $\mathrm{K}$ addition did not prevent the effect of salt stress on $\mathrm{K}$ absorption, the use of extra $\mathrm{K}$ at $100 \%\left(\mathrm{~S}_{4}\right)$ provided a $32.7 \%$ increase in its content as compared with solution $\mathrm{S}_{2}$ (Table 5).

\section{Table 5}

Summary of analysis of variance for potassium (K), sodium $(\mathrm{Na})$ and $\mathrm{K} / \mathrm{Na}$ ratio in the leaf tissue of melon cultivars subjected to potassium concentrations in salinized nutrient solution

\begin{tabular}{|cccc|}
\hline Cultivar & $\mathrm{K}\left(\mathrm{g} \mathrm{kg}^{-1}\right)$ & $\mathrm{Na}\left(\mathrm{g} \mathrm{kg}^{-1}\right)$ & $\mathrm{K} / \mathrm{Na}$ \\
\hline McLaren & $45.2 \mathrm{~b}^{*}$ & $9.2 \mathrm{~b}$ & $6.7 \mathrm{a}$ \\
SV1044MF & $53.0 \mathrm{a}$ & $14.9 \mathrm{a}$ & $6.0 \mathrm{a}$ \\
Nutrient solution & & & \\
$\mathrm{S}_{1}$ & $83.6 \mathrm{a}$ & $5.49 \mathrm{~b}$ & $15.7 \mathrm{a}$ \\
$\mathrm{S}_{2}$ & $31.3 \mathrm{~b}$ & $17.5 \mathrm{a}$ & $2.9 \mathrm{c}$ \\
$\mathrm{S}_{3}$ & $39.9 \mathrm{~b}$ & $16.5 \mathrm{a}$ \\
$\mathrm{S}_{4}$ & $41.6 \mathrm{~b}$ & $8.6 \mathrm{~b}$ & $5.3 \mathrm{~b}$ \\
$\mathrm{CV}(\%)$ & 14.6 & 23.7 & 20.6
\end{tabular}

Mean values followed by the same letter in the columns do not differ from each other by Tukey's test ( $p \leq 0.05)$. $S_{1}-$ standard nutrient solution, $2.5 \mathrm{dS} \mathrm{m}^{-1} ; \mathrm{S}_{2}$ - nutrient solution salinized with $\mathrm{NaCl}, 5.0 \mathrm{dS} \mathrm{m}^{-1} ; \mathrm{S}_{3}$ - nutrient solution salinized with $\mathrm{NaCl}+50 \% \mathrm{~K}, 6.5 \mathrm{dS} \mathrm{m}^{-1} ; \mathrm{S}_{4}$ - nutrient solution salinized with $\mathrm{NaCl}+100 \% \mathrm{~K}, 7.5 \mathrm{dS} \mathrm{m}^{-1}$. 
Other researchers have reported decreases in $\mathrm{K}$ levels in the melon plant tissue in response to salinity (Neocleous, Ntatsi, \& Savvas, 2017; J. L. A. Silva et al., 2021). Reductions in cytoplasmic $\mathrm{K}$ content may occur due to depolarization of the plasma membrane in roots under salt stress, and the activation of channels induced by reactive oxygen species favors $\mathrm{K}$ efflux (Flowers, Munns, \& Colmer, 2015).

In the evaluation of $\mathrm{Na}$ content, $\mathrm{cv}$. McLaren showed higher values, exceeding cv. SV1044MF by $62.6 \%$ (Table 4). The addition of $\mathrm{NaCl}$ to solution $\mathrm{S}_{2}$ provided an increase in the leaf $\mathrm{Na}^{+}$content, regardless of the analyzed cultivar, which resulted in a $218.9 \%$ higher value than those obtained with the standard nutrient solution $\left(\mathrm{S}_{1}\right)$. Additionally, the inclusion of extra $\mathrm{K}$ at $100 \%\left(\mathrm{~S}_{4}\right)$ reduced $\mathrm{Na}$ absorption by $50.9 \%$ when compared to solution $\mathrm{S}_{2}$ (Table 4). Tedeschi et al. (2017) and J. L. A. Silva et al. (2021) observed an increase in the Na content in the leaf tissue of melon. Under salt stress, competitive inhibition of $\mathrm{K}$ uptake by $\mathrm{Na}$ often interferes with $\mathrm{Na}$ in many K-dependent processes, inhibiting them. Sodium replaces $\mathrm{K}$ at binding sites in enzymes, resulting in the deactivation of enzymes and consequent interruption of metabolic processes (Flowers et al., 2015).

The cultivars did not differ significantly in their $\mathrm{K} / \mathrm{Na}$ ratio, averaging 6.3 (Table 5 ). In the analysis of the effect of nutrient solutions on this variable, the addition of $\mathrm{NaCl}$ to solution $\mathrm{S}_{2}$ was found to induce an $87.7 \%$ decrease when compared with solution S1. The $50 \%$ additional potassium contribution, in salinized solution $\mathrm{S}_{3^{\prime}}$, provided a 31.77 increase in the $\mathrm{K} / \mathrm{Na}$ ratio of the plants fertigated with this solution when compared with $\mathrm{S}_{2}$, although they did not differ. In addition, the plants fertigated with the solution containing an extra addition of $100 \%$ $\mathrm{K}\left(\mathrm{S}_{4}\right)$ showed a $173 \%$ higher $\mathrm{K} / \mathrm{Na}$ ratio than that obtained with solution $\mathrm{S}_{2}$ (Table 4).

Therefore, the studied genotypes appear not to differ in terms of salinity tolerance. The increase in ionic $\mathrm{K} / \mathrm{Na}$ ratio can act as a stress-tolerance mechanism, since the high $\mathrm{Na}$ content disturbs water absorption, besides damaging the photosynthetic apparatus (P. L. D. Morais et al., 2019). The K/ $\mathrm{Na}$ ratio is an important trait used by several authors to indicate the tolerance of plants to salinity (Gao, Yang, Wei, Huang, \& Zhang, 2020; R. C. P. Silva et al., 2020a), with the more tolerant genotypes exhibiting low $\mathrm{Na}$ contents and, consequently, high $\mathrm{K} / \mathrm{Na}$ ratios in their plant tissue.

\section{Conclusions}

The salinized nutrient solutions with extra potassium addition had a negative impact on the yield of melon fruits grown in a semi-hydroponic system. Extra $\mathrm{K}$ addition to salinized nutrient solution did not reduce the deleterious effect of salt stress, only $\mathrm{Na}$ absorption.

The addition of $\mathrm{NaCl}$ to nutrient solution reduced fruit weight, production, fruit diameter and pulp thickness. The evaluated melon cultivars do not differ in their tolerance to salt stress at the studied levels.

\section{References}

Association of Official Agricultural Chemists (1992). Official methods of analysis of the association of official analytical chemistry. Washington: AOAC. 
Ayers, R. S., \& Westcot, D. W. (1999). A qualidade de água na agricultura (2a ed.). Campina Grande: UFPB.

Castellane, P. D., \& Araújo, J. A. C. (1994). Cultivo sem solo: hidroponia. Jaboticabal: FUNEP.

Chakraborty, K., Bhaduri, D., Meena, H. N., \& Kalariya, K. (2016). External potassium (K+) application improves salinity tolerance by promoting $\mathrm{Na}^{+}$exclusion, $\mathrm{K}^{+}$accumulation and osmotic adjustment in contrasting peanut cultivars. Plant Physiology and Biochemistry, 103(6), 143-153. doi: 10.10 16/j. plaphy.2016.02.039

Chitarra, M. I. F., \& Chitarra, A. B. (2005). Póscolheita de frutas e hortaliças: fisiologia e manuseio (2a ed.). Lavras: UFLA.

Dantas, E. P., Queiroga, R. C. F., Silva, Z. L., Assis, L. E., Sousa, F. F., \& Ferreira, R. P. (2018). Produção e qualidade do meloeiro sob osmocondicionamento da semente e níveis de salinidade da água. Revista Verde de Agroecologia e Desenvolvimento Sustentável, 13(1), 8-15. doi: 10.18378/ rvads.v13i1.5013

Dawood, M. G., Abdelhamid, M. D., \& Schmidhalter, U. (2014). Potassium fertilizers enhances the salt tolerance of common bean (Phaseolus vulgaris L.). The Journal of Horticultural Science and Biotechnology, 89(2), 185-192. doi: 10.1080/14620316.2014.11513067

Dias, N. S., Lira, R. B., Brito, R. F., Sousa, O, N., Neto, Ferreira, M., Neto, \& Oliveira, A. M. (2010). Produção de melão rendilhado em sistema hidropônico com rejeito da dessalinização de água em solução nutritiva. Revista Brasileira de Engenharia Agrícola e Ambiental, 14(7), 755-761. doi: 10.1590/ S1415-43662010000700011
Dias, N. S., Morais, P. L. D., Sarmento, J. D. A., Sousa, O. N., Neto, Palácio, V. S., \& Freitas, J. J. R. (2018). Nutrient solution salinity effect of greenhouse melon (Cucumis melon L. cv. Néctar). Acta Agronómica, 67(4), 517-524, 2018. doi: 10.15446/acag. v67n4.60023

Empresa Brasileira de Pesquisa Agropecuária (2009). Manual de análises químicas de solos, plantas e fertilizantes (2a ed.). Rio de Janeiro: Embrapa Informação Tecnológica.

Epstein, E., \& Bloom, A. J. (2006). Nutrição mineral de plantas: princípios e perspectivas (2a ed.). Londrina: Planta.

Ferreira, D. F. (2014). SISVAR: a guide for its bootstrap procedures in multiple comparisons. Ciência \& Agrotecnologia, 38(2), 109-112. doi: 10.1590/S1413-705 42014000200001

Flowers, T. J., Munns, R., \& Colmer, T. D. (2015). Sodium chloride toxicity and the cellular basis of salt tolerance in halophytes. Annals of Botany, 115(3), 419-431. doi: 10.1093/aob/mcu217

Gao, L. W., Yang, S. L., Wei, S. W., Huang, D. F., \& Zhang, Y. D. (2020). Supportive role of the $\mathrm{Na}^{+}$transporter CmHKT1;1 from Cucumis melo in transgenic Arabidopsis salt tolerance through improved $\mathrm{K}^{+} / \mathrm{Na}^{+}$ balance. Plant Molecular Biology, 103(5), 561-580. doi: 10.1007/s11103-020-010 $11-0$

Gratieri, L. A., Cecílio, A. B., Fo., Barbosa, J. C., \& Pavani, L. C. (2013). Nitrogen and potassium concentrations in the nutrients solution for melon plants growing in coconut fiber without drainage. The Scientific World Journal, Boynton Beach, 2013(1), 1-10. doi: 10.1155/2013/546594 
Gurgel, M. T., Oliveira, F. H., Gheyi, H. R., Fernandes, P. D., \& Uyeda, C. A. (2010). Qualidade pós-colheita de variedades de melões produzidos sob estresse salino e doses de potássio. Revista Brasileira de Ciências Agrárias, 5(3), 398-405. doi: 10.5039/agraria.v5i3a507

Instituto Brasileiro de Geografia e Estatística (2020). Produção Agrícola Municipal: PAM 2020. Recuperado de https://sidra.ibge. gov.br/pesquisa/pam/tabelas

Instituto Adolfo Lutz (2008). Métodos físicoquímicos para análises de alimentos (4a ed.). São Paulo: Instituto Adolfo Lutz.

Kaya, C., Tuna, A. L., Ashraf, M., \& Altunlu, A. (2007). Improved salt tolerance of melon (Cucumis melo L.) by the addition of proline and potassium nitrate. Environmental and Experimental Botany, 60(3), 397-403. doi: 10.1016/j.envexpbot.2006.12.008

Koblitz, M. G. B. (2010). Bioquímica de alimentos: teoria e aplicações práticas. Rio de Janeiro: Guanabara Koogan.

Marschner, H. (2012). Mineral nutrition of higher plants (3nd ed.). London: Elsevier.

Morais, D. L., Aroucha, E. M. M., Oliveira, F. A., Medeiros, J. F., \& Nascimento, L. V. (2018). Impact of salinity on quality and postharvest conservation of gherkin (Cucumis anguria L.). Journal of Agricultural Science, 10(4), 167-177. doi: 10.5539/jas. v10n4p167

Morais, P. L. D., Dias, N. S., Oliveira, A. M., Sousa, O. N., Neto, Sarmento, J. D. A., \& Gonzaga, M. I. S. (2019). Effects of nutrient solution salinity on the physiological performance of melon cultivated in coconut fiber. Revista Caatinga, 31(3), 713-718. doi: 10. 1590/1983-21252018v31n321rc
Nascimento, C. S., Nascimento, C. S., \& Cecílio, A. B., $F^{\circ}$. (2020). N:K ratio for phenological growth stages of net melon cultivated in NFT hydroponic system. Revista Caatinga, 33(1), 108-115. doi: 10.1590/19 83-21252020v33n112rc

Neocleous, D., Ntatsi, G., \& Savvas, D. (2007). Physiological, nutritional and growth responses of melon (Cucumis melo L.) to a gradual salinity built-up in recirculating nutrient solution. Journal of Plant Nutrition, 40(15), 2168-2180, 2017. doi: $10.1080 / 01904167.2017 .1346673$

Oliveira, J. N., Filho, Silva, M. J., Jr., Medeiros, J. F., \& Vieira, R. C. (2020). Yield and leaf concentrations of nutrients of melon crop and fertility of soil fertigated with $\mathrm{N}$ and $\mathrm{K}$. Revista Brasileira de Engenharia Agrícola e Ambiental, 24(11), 749-755. doi: 10. 1590/1807-1929/agriambi.v24n11p749755

Pereira, F. A. L., Medeiros J. F., Gheyi, H. R., Dias, N. S., Preston W., \& Vasconcelos, C. B. L. (2017). Tolerance of melon cultivars to irrigation water salinity. Revista Brasileira de Engenharia Agrícola e Ambiental, 21(12), 846-851. doi: 10.1590/1807-19 29/agriambi.v21n12p846-851

Queiroz, I.S. R. D. (2016). Cultivo do meloeiro em sistema semi-hidroponico sob diferentes concentrações de potássio na solução nutritiva. Dissertação de mestrado, Universidade Federal Rural do SemiÁrido, Mossoró, RN, Brasil. Recuperado de https://ppgmsa.ufersa.edu.br/wpcontent/uploads/sites/59/2014/10/ Disserta\%C3\%A7\%C3\%A3o-ItaloSorac-Rafael-de-Queiroz.pdf 
Santos, J. M., Oliveira, F. A., Medeiros, J. F., Targino, A. J. O., Costa, L. P., \& Santos, S. T. (2018). Saline stress and potassium/ calcium ratio in fertigated eggplant. Revista Brasileira de Engenharia Agrícola e Ambiental, 22(11), 770-775. doi: 10. 1590/1807-1929/agriambi.v22n11p770775

Shi, X. L., Zhou, D. Y., Guo, P., Dong, J. L., Ren, J. Y., Jiang, C. J.,... Yu, H. Q. (2020). External potassium mediates the response and tolerance to salt stress in peanut at the flowering and needling stages. Photosynthetica, 58(5), 1141-1149. doi: 10.32615/ps.2020.070

Silva, F. H. A., Morais, P. L. D., Dias, N. S., Nunes, G. H. S., Morais, M. B., Melo, M. F., \& Nascimento, M. T. A. (2020b). Physiological aspects of melon (Cucumis melo L.) as a function of salinity. Journal of Plant Growth Regulation, 39(2), 1-17. doi: 10.1007/s00344-020-10190-5

Silva, J. L. A., Medeiros, J. F., Nascimento, I. B., Miranda, N. O., José, J. F., \& Souza, C. M. M. (2021). Nutritional status of Galia melon plants irrigated with saline water in different soils. Revista Dyna, 88(216), 7986. doi: 10.15446/dyna.v88n216.86209
Silva, M. C., Silva, T. J., Bonfim-Silva, E. M., \& Farias, L. D. N. (2014). Características produtivas e qualitativas de melão rendilhado adubado com nitrogênio e potássio. Revista Brasileira de Engenharia Agrícola e Ambiental, 18(6), 581-587. doi: 10.1590/S1415-43662014000600003

Silva, R. C. P., Oliveira, F. A., Oliveira, A. P., Medeiros, J. F., Alves, R. C., \& Paiva, F. I. G. (2020a). Bell pepper production under saline stress and fertigation with different $\mathrm{K}^{+} / \mathrm{Ca}^{2+}$ ratios in a protected environment. Acta Scientiarum. Agronomy, 42(1), e42498. doi: 10.4025/actasciagron.v42i1 .42498

Taiz, L., Møller, I. M., \& Murphy, A. (2017). Fisiologia e desenvolvimento vegetal (6a ed.). Porto Alegre: Artmed.

Tedeschi, A., Zong, L., Huang, C. H., Vitale, L., Volpe, M. G., \& Xue, X. (2017). Effect of salinity on growth parameters, soil water potential and ion composition in Cucumis melo cv. Huanghemi in North-Western China. Journal of Agronomy and Crop Science, 203(1), 41-55. doi: 10.1111/ jac. 12161

Yemn, E. W., \& Willis, A. J. (1954). The estimation of carbohydrate in plant extracts by anthrone. The Biochemical Journal, Colchester, 57(3), 508-514. doi: 10.1042/ bj0570508 
